Nataliia Kaziuka,

$\mathrm{PhD}$ (Economics), Associate Professor Ivano-Frankivsk National Technical University of Oil and Gas, Ivano-Frankivsk, Ukraine ORCID: 0000-0001-9440-7431

\title{
INVESTMENT ASPECTS OF THE TOURIST COMPLEX IN UKRAINE
}

The article deals with the investment problems of the tourist complex of Ukraine, as well as an assessment of its current state. It is emphasized that the country has considerable tourism potential, which is able to ensure the development of the tourism industry of Ukraine as one of the leading types of economic activity. It is substantiated why the tourist complex of the country has undergone significant changes in recent years. The factors that impede its development, including lack of public funding, unfavourable investment climate, imperfection of the legal framework and its non-compliance with international standards, are highlighted.

Key words: investment, tourism, investment climate, structural transformation, capital investment.

Relevance of the research topic. The tourism industry is extremely profitable and promising in the current dynamic environment. Positive changes in the tourism sector have an effective impact on such sectors as: construction, agriculture, transport, trade, communication, consumer goods production. Tourism is one of the most promising directions of structural transformation of the economy. Despite the global financial and economic crisis, the tourism sector is growing at about $10 \%$ per year, with international tourism accounting for $6 \%$ of total world exports and about $30 \%$ of world services exports.

Formulation of the problem. Ukraine is a country with enormous investment potential, especially in the tourism sector. This is driven by a favourable climate and abundant natural resources. The tourism sector is a promising sector for investment, since tourism is one of the main sectors of the world economy, as tourism is included in the daily life of the majority of the population. Also, this industry creates many economic benefits for the development of Ukraine, in particular contributes to the development of infrastructure (restaurants, hotels, etc.), contributes to income growth and improving the welfare of the population, etc. A significant portion of the tourism industry's growth is attributable to raising the revenue side of the country's budget 
through tax revenues. At the same time, tourism increases the opportunities for attracting different types of investments.

The purpose of the article is to study the current state of tourism investment in Ukraine, identify current problems and prospects for its development, directions of attracting additional investment funds.

Analysis of recent research and publications. It is worth noting that in recent years, both domestic and foreign scientists have been engaged in tourism investment issues, among which it is worth noting Sokhanvar A., Miller G., Simpson M., Twining-Ward L., Tudorache D., Simon T., Frent C., Musteat-Pavel M., Gkoumas A., Humeniuk V., Voroshylova G. and many others. A lot of information is available on the World Economic Forum, the World Tourism Organization and the State Statistics Committee of Ukraine. However, despite the increased attention of scientists to the problems of investment in tourism, theoretical and practical aspects of the development of the industry, a number of issues need further research and detail. In particular, the issues of investment attractiveness of the tourism sector in Ukraine and the prospects of investment in the economy remain undisclosed, which is of unconditional scientific interest and identifies the relevance of scientific research.

Presenting main material. Tourism is a priority area of the economy for most of the world, as tourism revenue reaches $50 \%$ [1]. For example, tourism is among the top three industries in countries such as the USA, France, Italy, Spain, Malaysia, Thailand, Egypt and Cyprus. Also, this industry is developing at a rather dynamic pace in several other countries, and is of key importance for economic development, as it contributes to the creation of new jobs, enhances the standard of living of the population, promotes the development of industrial infrastructure and increases foreign exchange earnings in the case of foreign investment. The most debatable issue is the question of financial support for the functioning of the country's economy. The revitalization of modern economic development is impossible without effective investment activity, especially in the sphere of tourism.

Ukraine is a European country that has unique natural and climatic resources, an optimal location. This may be the basis for increasing the economic attractiveness of the region. The great advantage of Ukraine is the presence of a large number of historical monuments of architecture and culture, including antique ones; attractive natural landscapes, including coastal and mountainous areas; significant volumes of cognitive tourism, such as historical and architectural reserves, theatres, museums, ancient castles, palaces, fortresses and parks.

In this regard, Ukraine as a country with available tourism resources is attractive enough for investment, but this is not a major prerequisite for increasing the overall tourist attractiveness of the country. On the background of investments intensification, it is occurred the growth of business activity not only in the sphere to which they are directed [3]. The achievement this requires needs the formation and 
renovation of a new material base, construction of new hotel complexes, sanitaryresort areas, modernization and reconstruction of historical cultural monuments. This will only be possible due to increased investment in tourism, but a favourable investment climate is needed to increase the financial income.

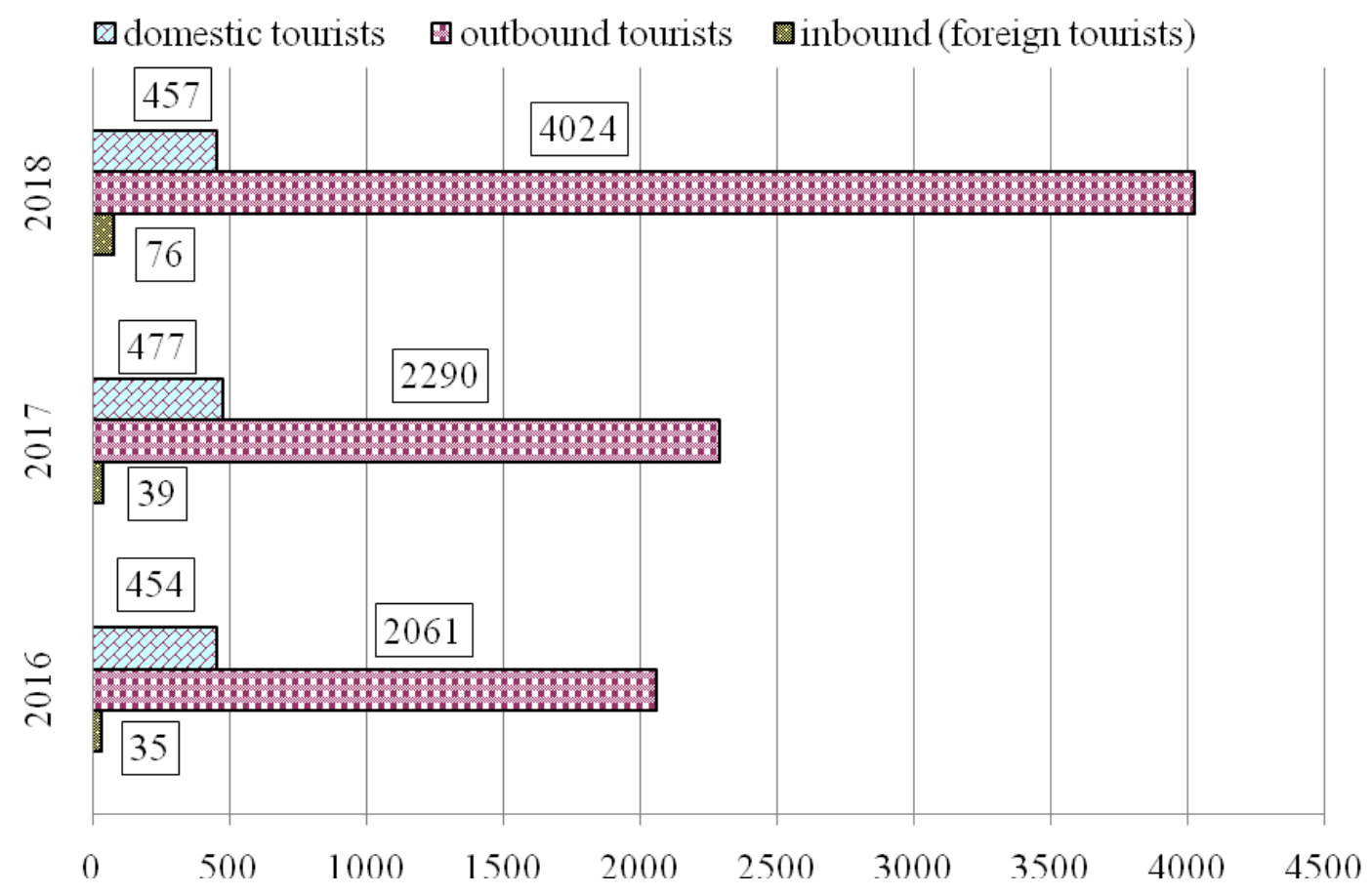

Figure 1. Dynamics of tourists by type in 2016-2018 (thousand)

Source: Tourism Statistics of Ukraine [8]

Investment climate refers to the economic, financial, and socio-political conditions in a country that affect whether individuals, banks, and institutions are willing to lend money and acquire a stake (invest) in the businesses operating there [2]. The investment climate in a country or region can be defined by a wide range of factors that determine whether domestic and foreign investment happens: by the soundness of macroeconomic policies, the strength of economic and political institutions, the functioning of the legal and regulatory framework, the quality of infrastructure and other services, amongst others [5]. In particular, the number of tourists sorted by tour operators and travel agents in Ukraine by type of tourism (thousand) is presented in Fig. 1.

The development of an effective investment policy in the future will ensure the formation of a favourable investment climate. Ukrainian economy has been in a difficult position since 2014 as a result of the military conflict in the east of the country, the occupation of Crimea by the Russian Federation and its aggressive policies. In this regard, the solution of the problem of providing a favourable investment environment for the development of entrepreneurship is quite relevant, since it depends on the restructuring of the economic and social life of the country, 
involvement in the international division of labour, the possibility of the economic sphere modernization.

The analysis results obtained indicate that the main problem today is the lack a unified targeted tourism development program in the state of justification not only benefits the tourism industry in the country and a clear strategy spelled out a list of effective measures at the national, regional and local levels [13]. Instead of conducting system market incorporation, open placement of shares on the stock market, attracting of foreign investment from leading economies of the world to the implementation of investment projects for the development of tourist infrastructure, there were contradictory non-market processes of appropriation of resort properties, and real powerful investments in the modernization of the resort and recreational sphere, its innovative development was not carried out at an adequate level [4].

However, the complication of current political trends in most cases has a negative impact on the investment climate and the international investment attractiveness of Ukraine. This is due to the activation of the following factors:

- significant imbalances of sectoral and regional development;

- high tax burden;

- outdated infrastructure;

- negative international image of the country;

- low level of investment risk insurance;

- lack of an effective legal framework on corporate governance.

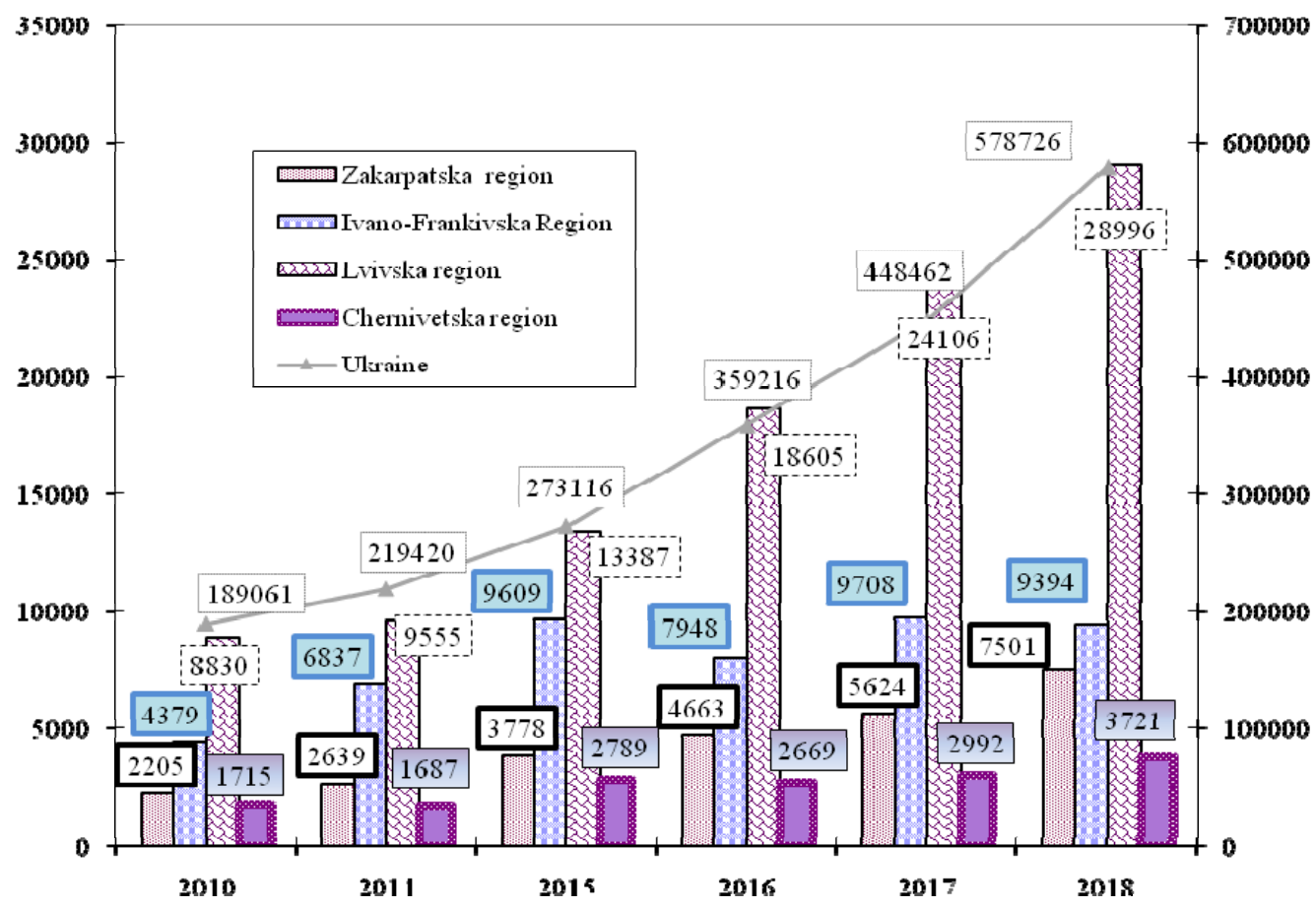

Figure 2. Dynamics of capital investment in in Ukraine and Carpathian region 2010-2018 (UAH million)

Source: Tourism Statistics of Ukraine [8]. 
Overall, capital investments in Ukraine increased by UAH 389665 million in 2018 compared to 2010 (fig.2). The most priority investment objects in economic practice are those which are characterized by the shortest payback period, significant export potential, high level of competitiveness in the domestic and foreign markets, and in the long term will be able to achieve a significant multiplier effect for activation of related industries.

Otherwise, The European Bank for Reconstruction and Development (EBRD) will continue cooperation with Ukrainian small- and medium-sized enterprises (SMEs) in the tourism industry in 2020 [12]. Aiming at the search of viable mechanisms of foreign investments involvement to Ukraine the government regularly holds business forums with foreign investors participation; indicated measures are to contribute to improve the investment image of Ukraine and to provide growth of foreign investment amounts and capital investments in the economy of the state [10].

The acceleration of tourism development in Ukraine is caused by a large number of negative factors, most of which are outdated. One of the main ones is the imperfection of organizational and methodological support of the enterprises of the sphere of tourism by the state bodies, the inconsistency of the comfort level of hotels, holiday homes and boarding houses - world quality standards, low investment in the development of the material base of tourist complexes.

Conclusions. In the current conditions of economic development of Ukraine, the main problem is the lack of effective programs for the development of small business in the restaurant and hotel services sector. At the same time, the declarative nature of the programs at the local level leads to the fact that the deduction of funds for the development of branches of the tourist complex is carried out on a residual principle, while their number remains small.

To sum up, the need to involve investors in the process of expanding the tourism sector is obvious. However, at present, there are a number of problems that hamper the attraction of additional financial resources, including the following: the feasibility of creating and functioning a public administration system for tourism activities with high tourism potential; the imperfection of the regulatory framework for regulating the tourist business and the lack of consistency with international standards; uneven amounts of financial revenues in the development of the material base of tourism business in Ukraine; unfavourable investment climate.

Therefore, the urgent needs of the tourist complex for investment require a clear and effective investment strategy for the future. It is capable of promoting the development of a favourable investment environment through the comprehensive implementation of investment policy instruments and the unification of common interests of private investors and the state. 


\section{REFERENCES}

1. Gkoumas A. (2019). Evaluating a standard for sustainable tourism through the lenses of local industry Hospitality \& Tourism Management. Heliyon, 5, P. 1-12.

2. Hayes A. (2019). Investment Climate - Investopedia. Retrieved from https:/www.investopedia.com/terms/i/investmentclimate.asp

3. Humeniuk V. (2018), Financial nature of resort multiplier, Financial and credit activity: problems of theory and practice, no. 25, vol 2, Ukraine, pp. 417-423. Retrieved from https://doi.org/10.18371/fcaptp.v2i25.136501.

4. Humeniuk V. (2019), Financial security of enterprises in resort and recreation sphere, Financial and credit activity: problems of theory and practice Vol 1, No 28 P. 87-94. Retrieved from https://doi.org/10.18371/fcaptp.v1i28.164013.

5. Investment climate and governance - European Bank for Reconstruction and Development (EBRD). Retrieved from https:/www.ebrd.com/what-we-do/sectorsand-topics/investment-climate-governance.html

6. Methodology Sustainable Destination Top 100, 2019. Retrieved August 24, 2019 from. http://sustainabletop100.org/methodology/.

7. Miller, G., Simpson, M., Twining-Ward, L., 2012, June 15. Study on the Feasibility of a European Tourism Indicator System for Sustainable Management at Destination Level. Retrieved June 19, 2012 from. https://www.surrey.ac.uk/ shtm/Files/Task\%201c)\%20Final\%20Case\%20Study\%20Review.pdf.

8. Official site of the State Statistics Service of Ukraine. Retrieved from http://www.ukrstat.gov.ua/

9. Sokhanvar A. (2019) Does foreign direct investment accelerate tourism and economic growth within Europe? Tourism Management Perspectives. Volume 29, January, Pages 86-96.

10. The investment climate in Ukraine - Ministry of Foreign Affairs of Ukraine. Retrieved from https://mfa.gov.ua/en/about-ukraine/economic-cooperation/ investment-climate-ukraine

11. Tudorache, D., Simon, T., Frenț, C., Musteat-Pavel, M. (2017). Difficulties and challenges in applying the european tourism indicators system (ETIS) for sustainable tourist destinations: the case of Braşov county in the Romanian carpathians. Sustainability 9 (10), 1879.

12. UNIAN: EBRD set to help Ukrainian businesses develop tourism in 2020 Kyiv Post. Retrieved from https:/www.kyivpost.com/ukraine-politics/unian-ebrd-setto-help-ukrainian-businesses-develop-tourism-in-2020.html?cn-reloaded=1

13. Voroshylova G. (2014). Specific features of tourism development in Ukraine: reality and perspectives. Економіка та управління національним господарством, 4, p. 169-173. 